\title{
Turističko brendiranje destinacije na primjeru Podravine
}

Robert Baćac*

robert.bacac@pu.t-com.hr

https://orcid.org/0000-0001-8427-9085

Damir Demonja**

ddemonja@irmo.hr

https://orcid.org/0000-0002-4186-5137 https://doi.org/10.31192/np.19.1.14

UDK: 338.48-44(497.525)

Izvorni znanstveni rad / Original scientific paper

Primljeno: 3. kolovoza 2020.

Prihvaćeno: 16. studenog 2020.

Podravina kao kulturno-povijesni pojam prepoznatljivo je zemljopisno područje u Republici Hrvatskoj koje obuhvaća teritorij između rijeke Drave, gore Bilogore $i$ Kalničkog gorja. Danas je ovo područje dio jedinstvene administrativne i političke cjeline Koprivničko-križevačke županije. U turističkom smislu Podravina čini zasebnu cjelinu, posebno povijesno, kulturno, prirodno i socijalno odredište $s$ vlastitim specifičnostima $i$ resursima. Turistički gledano, Podravina još nije iskoristila svoju konkurentsku prednost s obzirom na brendiranje, odnosno izgradnju prepoznatljivog imidža te tržišnu prepoznatljivost $i$ pozicioniranost. Brendiranje Podravine je osmišljavanje konkurentnog identiteta koje će diferencirati ovo odredište od svih drugih. Sam brend određuju osnovne karakteristike odredišta, njegove prednosti koje proizlaze iz resursne osnove, što je njegova posebnost, $i$ čini ga prepoznatljivim i različitim od konkurenata. U tom smislu potrebno je detektirati i definirati Točke jednakosti (Points of Parity) $i$ Točke različitosti (Points of Difference) na temelju kojih bi odredište Podravina izgradilo svoje vrijednosti i prepoznatljivosti u turističkom smislu. Za uspješno brendiranje Podravine kao turističkog odredišta potrebno će biti definirati čimbenike brendiranja koji su ključni za izgradnju brenda.

Ključne riječi: brendiranje, Podravina, prepoznatljivost odredišta, turističko pozicioniranje, turizam.

\footnotetext{
* Robert Baćac, mag. oec., samostalni konzultant, Giardini 2, HR-52100 Pula.

**Dr. sc. Damir Demonja, znanstveni savjetnik u trajnom zvanju, Institut za razvoj i međunarodne odnose, IRMO, Odjel za međunarodne gospodarske i političke odnose, Ljudevita F. Vukotinovića 2, HR-10000 Zagreb.
} 


\section{Uvod}

Podravina je prepoznatljivo zemljopisno područje u Republici Hrvatskoj s odgovarajućim brojem jedinstvenih i vrijednih turističkih sadržaja koji su potencijali za privlačenje turista. Međutim u primjeru Podravine ti sadržaji nisu tako artikulirani da Podravinu snažnije, jasnije diferenciraju u odnosu na konkurenciju, a turistima treba ponuditi jedinstveno iskustvo koje će se temeljiti na sinergiji postojećih sadržaja Podravine. To će biti moguće postići pokretanjem procesa izgradnje turističkog brenda Podravine, o čemu se raspravlja u ovom znanstvenom radu. U njemu se predstavljaju i obrazlažu razlozi i potrebe, odnosno nužnost brendiranja destinacije s referiranjem na globalni kontekst i kompetitivno okruženje, tumače se tipovi brendiranja, i po prvi puta se za Podravinu definiraju PoPs (Points of Parity), točke jednakosti i PoDs (Points of Difference), točke različitosti destinacije. Pri njihovu definiranju korištene su metoda analize i metoda komparacije $\mathrm{s}$ brendiranim turističkim destinacijama u Hrvatskoj (Istra, Baranja) i onima europskima (Toskana, Provansa, Škotska), dok je za definiranje točki različitosti korištena i metoda idealnih tipova. Na temelju njih se predlažu i objašnjavaju ključni atributi s pomoću kojih bi se mogla brendirati Podravina, zaključno s navođenjem koraka procesa izgradnje turističkog brenda Podravine i uspješnog implementiranja svih ključnih točaka stvaranja prepoznatljive tržišne robne marke destinacije Podravina. S obzirom da je pregledom recentne znanstvene i stručne literature utvrđeno da se o turističkom brendiranju Podravine nije raspravljalo u hrvatskoj akademskoj javnosti, ovaj znanstveni rukopis jedan je od prvih koji obrađuje ovu važnu temu.

\section{Brendiranje destinacije}

\subsection{Globalni kontekst brendiranja destinacije}

Od 2000. godine bilježi se kontinuirano povećanje i ekspanzija turizma na globalnoj razini. Turizam karakteriziraju promjene u preferencijama i ponašanjima turista, što rezultira širokom diversifikacijom turističkih usluga i turističke ponude uopće. Razvoj turističke ponude smjera na ciljne skupine, odnosno niša-ponudi, koja je usko povezana s destinacijskim pristupom u sadašnjem razvoju turizma. Današnji, suvremeni turizam usko je povezan s destinacijom, odnosno odredišnim razvojem ponude te cjelokupnom turističkom infrastrukturom i suprastrukturom. To su razlozi što se na turističkom tržištu pojavljuje sve veći broj destinacija, nacionalnih, regionalnih, lokalnih (mikro-lokacijskih), sa specifičnom konkurentnom turističkom ponudom. Ovakav pristup i ovakva dinamika omogućili su da turizam postane jedan od najbrže rastućih 
gospodarskih sektora na globalnom tržištu, pretvorivši ga u ključni pokretač društveno-gospodarskog rasta međunarodne ekonomije. Taj rast doprinosi sve većom raznolikošću i konkurencijom među odredištima.

Turizam nije sam sebi svrha, što dokazuje multiplikativni efekt turističke potrošnje, ali i direktan utjecaj na razvoj ostalih gospodarskih sektora: graditeljstvo, poljoprivrednu proizvodnju i prehrambenu industriju, industriju visokih tehnologija, telekomunikacije, automobilsku industriju i industriju prijevoznih sredstava uopće i drugih. Turizam je postao jedan od glavnih čimbenika međunarodne trgovine, a istodobno i jedan od glavnih izvora prihoda za destinacije (regije i zemlje) gdje se sustavno i kontrolirano razvija. Globalno širenje turizma rezultiralo je nizom pogodnosti za lokalno gospodarstvo, ali i zapošljavanjem u mnogim gospodarskim sektorima koji su direktno i indirektno povezani s turizmom.

Prema podacima Svjetske turističke organizacije turizam čini $10 \%$ ukupnog svjetskog BDP-a. ${ }^{1}$ Jedno od deset radnih mjesta je u turizmu. Turizam ostvaruje 1,4 bilijuna USD izvozom roba, i čini ukupno 7 \% ukupnog svjetskog izvoza, te ostvaruje $29 \%$ ukupnog svjetskog izvoza usluga. ${ }^{2}$

Turistički barometar UNWTO-a navodi da je u razdoblju od siječnja do rujna 2019. godine u svijetu zabilježen porast od $4 \%$ međunarodnih dolazaka i noćenja u odnosu na 2018. godinu u istom razdoblju. ${ }^{3}$ Regionalno gledano, najveći porast, od $9 \%$, ostvaren je na Bliskom Istoku; Azija, Pacifik i Afrika bilježe rast od $5 \%$, u Europi se broj turista povećao za $3 \%$, dok Sjeverna i Južna Amerika ostvaruju rast od $2 \%{ }^{4} \mathrm{Na}$ temelju ovih podataka može se zaključiti da motivacija za turističkim putovanjem raste s obzirom na sve veću diversifikaciju i ekspanziju ponude i specifičnih turističkih usluga destinacijskog tipa. Održivi rast u većini glavnih destinacija i stalni odmak od drugih doveli su do pozitivnih rezultata. Globalno ekonomsko usporavanje, trgovinske napetosti i sve veći geopolitički izazovi, socijalni nemiri, dugotrajna neizvjesnost o Brexitu i slabije poslovno povjerenje utjecali su na rast međunarodnog turizma. Propast glavne turističke grupe Thomas Cook i nekih malih europskih avioprije-

\footnotetext{
${ }^{1}$ Svjetska turistička organizacija (United Nations World Tourism Organization - UNWTO) je pod-organizacija Ujedinjenih naroda, utemeljena radi praćenja, reguliranja i razvijanja turizma u svijetu, sa sjedištem u Madridu. Vodeća je međunarodna organizacija u području putovanja i turizma, osnovana 1976. godine sa svrhom da pomaže zemljama u maksimizaciji pozitivnih utjecaja turizma na gospodarstvo (npr. u kreiranju novih radnih mjesta, izgradnji infrastrukture i sl.) uz istovremeno smanjenje negativnog utjecaja razvoja turizma. Članice su 138 zemalja, $\mathrm{s}$ više od 350 pridruženih članova (od vlada pojedinih zemalja do turističkih udruženja i privatnog sektora poput zrakoplovnih kompanija, hotela i turoperatora). Hrvatska je članica od 1993. (http://www2.unwto.org/) (31.07.2020).

${ }^{2}$ UNWTO, International Tourism Higlights 2019 Edition, Madrid, 2019, 8; https://www.eunwto.org/doi/pdf/10.18111/9789284421152 (31.07.2020).

${ }^{3}$ UNWTO, World Tourism Barometer and Statistical Annex, 17 (2019) 4, https://www.e-unwto. org/doi/abs/10.18111/wtobarometereng.2019.17.1.4 (31.07.2020).

${ }^{4}$ Isto.
} 
voznika, privremeno je utjecala na neka ključna turistička odredišta, posebno u Europi i Americi. ${ }^{5}$

SAD predvode povećanje međunarodne turističke potrošnje, podržane snažnim dolarom. Francuska je izvijestila o najvećem porastu od deset najboljih tržišta, pokazujući drugu godinu zaredom povećanje potražnje, dok je međunarodna turistička potražnja u Kini u prvoj polovici 2019. godine porasla za $14 \%$, premda su rashodi pali za $4 \%$ u odnosu na isto razdoblje prošle godine. ${ }^{6}$

UNWTO predviđa da će do 2030. godine vrijednost međunarodnih turističkih dolazaka vrijediti 1,8 milijardi američkih dolara, odnosno porast će 3,3 $\%$ na godišnjoj razini. Financijski gledano, u 2018. godini međunarodni prihodi od turizma realno su porasli za $4 \%$ (uzimajući u obzir promjene tečaja i inflacije) s ukupno procjenjenom zaradom u odredištima od 1.700 milijardi američkih dolara?

Današnji turisti su istraživači. Oni su turisti treće generacije, zahtjevni su, znaju što žele i putuju zbog motiva, a ne samo zbog potrebe za putovanjem (turisti prve generacije) ili zato da posjete određeno mjesto (turisti druge generacije). Turisti treće generacije imaju želju snažno proživjeti svoj godišnji odmor i/ili putovanje, doživjeti iskustvo novih i različitih mjesta, imati individualnu, personaliziranu uslugu i otkriti autentične stvari. Oni žele biti dio lokalne, jedinstvene i teško ponovljive (replicirane) kulture. Žele doživjeti nove kulture, spojiti iskustva kroz različite vrste putovanja, susretati se i komunicirati s lokalnim ljudima i proživjeti autentično iskustvo. ${ }^{8}$ Za destinacije ti čimbenici znače ogroman izazov jer za privlačenje gostiju moraju biti autentični i kreativni, nudeći mješavinu avanture i opuštanja. Osim toga, destinacije trebaju ponuditi besprijekorno iskustvo putovanja koristeći nove tehnologije kako za komunikaciju (digitalne taktike), tako i za stvaranje atrakcija (primjerice, tehnologija proširene stvarnosti).

Od 2000. godine na globalnoj razni dolazi do važnih tehnoloških promjena koje posebno utječu na brži razvoj turizma, putovanja i mobilnost turista uopće. Promjene u tehnologiji bitno su olakšale pristup informacijama i, općenito, informiranosti o turističkoj ponudi. S druge strane, novi tehnološki pristupi značajno su omogućili bolju tržišnu vidljivost turističke ponude u destinacijama.

Najvažnija tehnološka promjena koja je olakšala razmjenjivanje informacija je internet. Srdinom 2019. godine zabilježeno je 4,5 milijardi korisnika interne-

\footnotetext{
${ }^{5}$ Thomas Cook, https://www.thomascook.com/ (31.07.2020).

${ }^{6}$ UNWTO, World Tourism Barometer and Statistical Annex...

7 UNWTO, International Tourism Higlights 2019 Edition...

${ }^{8}$ David WEAVER, Enlightened mass tourism as a 'third generation' aspiration for the twenty-first century, u: Michael HUGHES, David WEAVER, Christof PFORR (ur.), The Practice of Sustainable Tourism. Resolving the Pardox, Abingdon, UK, Routledge, 2015, 11-23.
} 
ta u svijetu. ${ }^{9}$ Internet i s njim povezane tehnologije uvelike su otvorili prilike za personaliziranu komunikaciju i društveno umrežavanje. To je utjecalo na povećanje turističke potrošnje zbog lakše organizacije putovanja, od bookinga do transfera, korištenjem mobilnih uređaja. S druge strane, destinacije mogu u realnom vremenu na brz i odgovarajući način marketinški promovirati i prodavati turističke usluge bilo gdje i bilo kojim ciljnim skupinama, a kroz proces brendiranja povećavati svoju tržišnu vidljivost. Destinacije imaju na raspolaganju revolucionaran način da kroz korisnički generirani sadržaj »koriste« svoje posjetitelje kao promotore turističke ponude objavljivanjem komentara, fotografija, videozapisa i on-line dijaloga o njihovu odmoru. Posebno se to odnosi na komunikaciju putem društvenih mreža. Internet je omogućio da i manje destinacije vrlo ograničenim financijskim sredstvima za marketing i promociju mogu doseći svoju ciljanu publiku, te na taj način biti konkurentne sa svojim turističkim uslugama. ${ }^{10}$

Neizbježno, s povećanjem turističkog prometa rasla je i potražnja za prijevozom putnika. Tehnološke promjene $u$ industriji prijevoza pozitivno su se reflektirale na mobilnost putnika. Prije svega to se odnosi na proizvodnju prijevoznih sredstava, osobnih automobila, autobusa, zrakoplova, vlakova, putničkih brodova, odnosno ugradnju visoko sofisticiranih elektronskih uređaja te na digitalizaciju i programiranje, što je prijevozna sredstva učinilo bržima i sigurnijima. Veći broj putnika i prijevoznih sredstava rezultira i izgradnjom nove prijevozne infrastrukture i modernizacijom postojeće, kao što su autoceste, zračne luke, željezničke pruge i putničke morske luke.

\subsection{Kompetitivno okruženje u funkciji brendiranja destinacije}

Brendiranje destinacije umnogome ovisi o kompetitivnom okruženju. Današnje kompetitivno okruženje na svim razinama, od nacionalnih preko regionalnih do mikro-lokacijskih, vrlo je snažno i zahtjevno. Budući da se turizam smatra značajnim faktorom koji doprinosi prije svega lokalnoj ekonomiji i gospodarskom razvoju, razumljivo je da se svake godine ponudom konkurentne turističke usluge uključuje sve više destinacija. Ostvariti bolju tržišnu vidljivost danas je vrlo zahtjevno. Proces brendiranja jedne destinacije nikada nije bio složeniji i zahtijeva pomnu i permanentnu akciju s točno i jasno definiranim strategijama komuniciranja da bi se postigao željeni rezultat. Za tržišno pozicioniranje destinacije vrlo je važno istražiti i identificirati čimbenike motivacije turista, njihove preferencije i načine ponašanja. Općenito gledano, priroda, kultura, baština i avantura često se među posjetiteljima navode kao važni elementi

\footnotetext{
${ }^{9}$ Internet World Stats, Usage and Population Statistics, https://www.internetworldstats.com/ stats.htm (31.07.2020).

${ }^{10}$ Alberto J. CASTAÑEDA, Dolores M. FRÍAS, Michael A. RODRÍGUEZ, The influence of the Internet on destination satisfaction, Internet Research, 17 (2007) 4, 402-420.
} 
u njihovoj idealnoj destinaciji za odmor. $U$ tom smislu, destinacije imaju izazov kreirati takav turistički proizvod koji će zadovoljiti ove motive, odnosno kreirati maštovite načine doživljavanja svoga prostora i atrakcijske osnove te istodobno potencirati svoje jake konkurentske snage postojećih resursa koje destinaciju čini različitom od drugih. ${ }^{11}$ Konkurentski identitet gradi se na specifičnostima kojima turistička destinacija raspolaže, a koje ih mogu uvelike segmentirati i razlikovati od konkurentskih prednosti ostalih kompetitivnih destinacija.

Brendiranje destinacije jest kreiranje konkurentnog identiteta koji diferencira destinaciju od svih ostalih. Sam brend odnosi se na osnovne karakteristike destinacije, njezine prednosti koje proizlaze iz resursne osnove, što oblikuje njezinu osobitost i čini je prepoznatljivom i različitom od konkurenata. Brend čini samu bit destinacije, odnosno ono po čemu je destinacija specifična i što je izdvaja od ostalih. Brend nije logotip, slogan (krilatica, fraza, moto, kratki skup riječi), proizvod ili marketinška kampanja koja se provodi radi povećanja tržišne vidljivosti na turističkim tržištima, već dinamičan odnos između turističkog proizvoda i potencijalnog posjetitelja-turista, odnosno percepcije potencijalnog posjetitelja-turista prema destinaciji koja se brendira. ${ }^{12}$ Brend je temelj iz kojeg proizlaze komunikacija s tržištima (kanali prodaje, promotivni kanali, i drugo) i kreiranje vizualnog identiteta koji služi za lakše komuniciranje na tržištima. Osnovni princip brendiranja polazi od percepcije potencijalnog posjetitelja-turista na temelju fizičkih atributa turističkih proizvoda ili usluga kreiranih u destinaciji. Uspješnost brenda mjeri se od prihvaćanja potencijalnih posjetitelja-turista, tj. njihove zainteresiranosti i motiviranosti za turističke proizvode i usluge u destinaciji i, naposljetku, njihove percepcije, odnosno kako potencijalni posjetitelj-turist percipira samu destinaciju. Uspješan brend je prepoznatljiv kada ga potencijalni posjetitelji-turisti percipiraju kao relevantnog, jedinstvenog, on ima dodanu vrijednost i najviše odgovara njihovim potrebama. Brendiranje je proces koji uključuje skup tehnika i aktivnosti kojima se osigurava da potencijalni posjetitelji-turisti razumiju destinacijski turistički proizvod (samu destinaciju) na poželjan i prihvatljiv način. Brendiranje dosljedno i permanentno ističe destinacijske prednosti kroz atraktivan turistički proizvod i zadatak mu je osigurati pozitivnu percepciju. Jer brendiranje ima zadatak predstaviti posebnost destinacije u smislu karakterističnosti, nezabo-

\footnotetext{
${ }^{11}$ Ayşen CIVELEK, The role of branding in destination marketing, International Journal of Business Tourism and Applied Sciences, 3 (2015) 1, 65-69.

${ }^{12}$ Brent J. R. RITCHIE, Robin J. B. RITCHIE, The branding of tourism destinations - Past Achievements and Future Challenges. A basic Report Prepared for Presentation to the 1998 Annual Congress of the International Association of Scientific Experts in Tourism Marrakech, Morroco, September 1998, u: P. KELLER (ur.), Destination Marketing, Reports of The $48^{\text {th }}$ Aiest Congress, Marrakech, 1998, 1998, http://citeseerx.ist.psu.edu/viewdoc/download?doi=10.1.1.201. 9520\&rep=rep1\&type $=$ pdf $(31.07 .2020)$.
} 
ravnosti i vrijednosti za definirane tržišne segmente, ali i održavati odanost posjetitelja-turista. ${ }^{13}$

\subsection{Tipovi brendiranja}

S aspekta turizma, turističkih proizvoda i turističkih usluga definirane su četiri vrste brendiranja čiji je cilj kreiranje prepoznatljivosti destinacije bez obzira na to je li riječ o nacionalnoj, regionalnoj ili lokalnoj razini. ${ }^{14} \mathrm{~S}$ obzirom na osnovnu svrhu brendiranja radi postizanja tržišne vidljivosti i prihvatljivosti od potencijalnih posjetitelja-turista u smislu stvaranja pozitivne percepcije, brendiranje se može podijeliti na nekoliko tipova, koje je moguće implementirati i u procesu brendiranja Podravine:

- Brendiranje turističkog proizvoda: odnosi se na brendiranje pojedinog turističkog proizvoda unutar destinacije, tj. naglasak je na pojedini proizvod koji je jaka snaga same destinacije i njegovim brendiranjem postižu se puno bolji rezultati u smislu vidljivosti i pozitivne percepcije od destinacijskog brendiranja.

- Brendiranje turističke usluge: odnosi se na interakciju između pružatelja usluga i korisnika. Odvija se u određenom vremenskom razdoblju i ovisi o tome je li korisnik uspio dobiti percipiranu vrijednost za uloženi novac. Obično je riječ o uslugama prijevoza, npr. avio-kompanija i usluga smještaja, primjerice hotela (poznatih hotelskih brendiranih lanaca).

- Brendiranje destinacije (odredišta): odnosi se na određeno područje determinirano povijesnim, kulturnim, prirodnim i ostalim prepoznatljivim faktorima. Brendiranje destinacije obavezno sadrži sve elemente koji karakteriziraju područje, a to su: ljudi i njihov način života, tradicija i baština, kultivirani i prirodni krajolik, jezik i narodno stvaralaštvo, tipični proizvodi i proizvodi obrtništva. Obično su elementi naslijeđeni iz prošlosti i nadograđivani, premda mogu biti i ponovno izgrađeni (npr. Dubai). Pri destinacijskom brendiranju, gledajući s aspekta potencijalnog posjetitelja-turista, primarno je usredotočiti se na percepciju odredišta i njegovu emocionalnu privlačnost kao i na pitanje zbog čega bi potencijalni posjetitelj-turist trebao izabrati neku destinaciju. Destinacija mora komunicirati svoj način života, odnosno lifestyle koji je vrlo snažan pokretač razvoja inovativnih i integriranih, modernih, turističkih usluga, te mora stvoriti emocionalnu vezu sa svojom publikom.

\footnotetext{
${ }^{13}$ Simon ANHOLT, Handbook on Tourism Destinations Branding, Madrid, World Tourism Organisation i European Travel Commision, 2009, http://www.etc-corporate.org/uploads/invitations/invite_pdf/2/Draft_ETC_UNWTO_Handbook_Tourism_Destination_Branding.pdf (31.07.2020).

${ }^{14}$ Isto, $1-32$.
} 
- Brendiranje mjesta: odnosi se na kreiranje tržišne vidljivosti i pozitivne percepcije pojedinog grada, malog mjesta, sela ili lokacije (npr. Stonehenge u Velikoj Britaniji). Cilj brendiranja mjesta je prenijeti genius loci, odnosno »duh mjesta« kao nešto što je atraktivno za posjet. »Duh mjesta" određen je materijalnim elementima (građevine, lokaliteti, pejzaži, rute, objekti) i onim nematerijalnim (memorije, usmena predaja, rituali, festivali, tradicionalno znanje, vrijednosti, mirisi), fizičkim i duhovnim elementima koji daju značenje, vrijednost, emociju i začudnost mjestu. Ne bi trebalo odvajati duh od mjesta, nematerijalno od materijalnog i smatrati ih oprečnima, već postoje načini na koje oni utječu jedan na drugi i time se međusobno definiraju. »Duh mjesta» se stvara raznim društvenim čimbenicima, njegovim kreatorima i menadžerima, kao i korisnicima, koji svi aktivno pridonose u stvaranju značenja. Shvaćen kao odnosni koncept, »duh mjesta" poprima pluralni i dinamični karakter, sposoban sadržavati mnogostruka značenja i posebnosti, promjenjiv vremenom i pripadajući različitim skupinama. Ovaj dinamičniji pristup primjereniji je današnjem globaliziranom svijetu koji karakterizira kretanje transnacionalne populacije, svijetu izmještenih populacija, povećanih kulturnih kontakata, pluralističkih društava i mnogostrukih vezanosti uz mjesto. »Duh mjesta» nudi jače razumijevanje životnog, a istodobno i trajnog karaktera spomenika, lokaliteta i kulturnih krajolika. On pruža bogatiju, dinamičniju i sveobuhvatniju viziju kulturne baštine. »Duh mjesta" postoji, u ovom ili onom obliku, praktično u svim kulturama svijeta i čine ga ljudska bića koja reagiraju na svoje društvene potrebe. Zajednice koje nastanjuju neko mjesto, posebno kada su to tradicionalna društva, trebale bi zauzeto čuvati njegovu memoriju, vitalnost, kontinuitet i duhovnost. ${ }^{15}$

Navedeni tipovi brendiranja u svakom se trenutku procjenjuju u smislu usredotočivanja na načine kako se mogu najbolje iskoristiti. Stoga se unutar navedenih tipova brendiranja može napraviti i podjela na:

- Tematsko brendiranje: odnosi se na usredotočivanje na neki segment života u destinaciji koji destinaciju čini jedinstvenom, prepoznatljivom i neponovljivom. Kao primjer ove vrste brendiranja može se istaknuti tirolski način života u Austriji ili provansalski u Francuskoj. To konkretno znači da su i tirolski i provansalski način doživljaja života jedinstveni i neponovljivi i zato primjereni za brendiranje. ${ }^{16}$

\footnotetext{
${ }^{15}$ INTERNATIONAL COUNCIL ON MONUMENTS AND SITES, Québec Declaration on the preservation of the spirit of place, 2008, https://whc.unesco.org/uploads/activities/documents/ activity-646-2.pdf (31.07.2020).

${ }^{16}$ Anholt, Handbook on Tourism Destinations Branding...
} 
- Brendiranje manifestacija i/ili događaja: odnosi se na stvaranje identiteta destinacije putem manifestacija i događaja (npr. festivali). Događaj može biti autohtonog karaktera koji je usko vezan za tradiciju i baštinu kraja bez obzira na to je li riječ o materijalnoj ili nematerijalnoj baštini ili, pak, to može biti međunarodni događaj vezan za neku temu (npr. muzički festival, sportski događaji, i slično). Ovakvi događaji imaju za cilj pojačati vrijednost destinacije ili, čak, potpuno izmijeniti percepciju i sliku o destinaciji. ${ }^{17}$

Proces brendiranja provodi se radi prepoznavanja destinacije komuniciranjem konkurentskih prednosti (ono što čini destinaciju drukčiju od drugih) prema potencijalnim posjetiteljima-turistima. Važno je istaknuti da brendiranje destinacije ne smije biti usmjereno samo na interese potencijalnih posjetitelja-turista, već mora biti prihvaćeno od domaćeg, lokalnog stanovništva te odražavati i uvažavati njihove stavove i težnje. Stoga brendiranje od strane lokalne samouprave i svih dionika u procesu mora biti izraz zajedničke vizije destinacije u smislu njezinog daljnjeg oblikovanja putem razvoja i investicija. To znači da je ključno da lokalna samouprava stvarno razumije potrebe svoga područja da bi se omogućio održiv i odgovoran ekonomski rast pametnim iskorištavanjem postojećih resursa. Ako percepcija razvoja lokalne samouprave $\mathrm{i}$ investitora s jedne strane, i lokalnog stanovništva s druge strane, nisu u harmoničnom odnosu, tada će i ekonomski učinak biti slab. Ako su u harmoniji tada se može očekivati jaka sinergija u jačanju vrijednosti destinacije. Ponašanje lokalnog stanovništva bitno utječe na percepciju potencijalnih posjetitelja-turista u smislu njeguje li lokalno stanovništvo prema njima osjećaj prihvaćanja ili odbojnost. Pozitivna vanjska percepcija u tom smislu može bitno doprinijeti kvaliteti života kroz uključivanjem lokalnog stanovništva u procese (primjerice, tzv. privatno iznajmljivanje). Ne treba očekivati da će brendiranje destinacije koje potencira i promovira »duh mjesta « riješiti sve poteškoće gospodarskog i socijalnog razvoja, ali može dati izvrstan poticaj i prednost pred ostalim destinacijama u identifikaciji, učinkovitom upravljanju, novom razvoju, privlačenju ulaganja, stvaranju pozitivne klime zapošljavanja i poduzetništva, odnosno može rezultirati društveno korisnim aspektima.

Sljedećih pet kriterija važni su za kreiranje brenda: 1. snažno gospodarstvo, uključujući dinamičan poslovni sektor i kvalificiranu radnu snagu; 2. prepoznatljiv osjećaj mjesta i povijesti; 3 . vrhunska kvaliteta života i živa kultura; 4. zaštita okoliša $\mathrm{i}$ »zeleno« usmjerenje s kvalitetnim otvorenim prostorom; 5. usredotočenost na razvoj više sektora, $\mathrm{s}$ održivim transportom i dobrom prometnom povezanosti. ${ }^{18}$

\footnotetext{
${ }^{17}$ Isto, 20-21.

${ }^{18}$ Isto, 1-5.
} 
Brending pozicioniranje odnosi se na razumijevanje što potencijalni posjetitelji-turisti na tržištu misle o destinaciji, odnosno kako reagiraju na nastojanja, potvrđuju li ih i prihvaćaju. Svrha pozicioniranja je postizanje najbolje pozitivne pozicije na tržištima i pozitivne slike o destinaciji u percepciji potencijalnih posjetitelja-turista u odnosu na konkurente.

U ovome radu raspravlja se o brendiranju Podravine kao turističkog odredišta (destinacije), odnosno njezinim karakteristikama koje ističu destinacijsku autentičnost i diferencijaciju od ostalih konkurentnih destinacija. Istražuju se i predlažu specifični destinacijski atributi i vrijednosti (kulturološke, povijesne, zemljopisne, gospodarske i druge), jer oni naglašavaju autentičnost Podravine i na njima se može izgraditi turistička prepoznatljivost, odnosno brend, i poboljšati turistička konkurentnost. Brend ili marku kao ime definira pojam, znak, simbol, oblik ili kombinacija svega navedenoga, a namjena joj je identificiranje dobara ili usluga jednog prodavatelja ili grupe prodavatelja te njihovo diferenciranje od konkurenata. ${ }^{19}$

Brendiranje $u$ turizmu je proces koji neku destinaciju njezinim posebnostima izdvaja od drugih destinacija i na taj način stvara poseban identitet te destinacije. Najveći uspjeh stvaranja identiteta destinacije postiže se isticanjem njezinih najvećih posebnosti, odnosno autentičnosti. Kvalitetno brendirana turistička regija stvara prepoznatljivost i ističe se u svjetskim krugovima, privlači raznovrsna ulaganja, obrazovane i stručne pojedince, a djeluje i na povećanje izvoza regije, odnosno države. Brendiranjem se ugrađuju vrijednosti koje trebaju biti dovoljno snažne i privlačne da bi privukle potrošača/korisnika u posjet samoj destinaciji. ${ }^{20}$

U nastavku se razmatraju ključni atributi destinacije Podravina koji posjetiteljima, u turističkom smislu, mogu ponuditi iskustva i doživljaje koji će imati dodanu vrijednost $\mathrm{i}$, istovremeno, diferencirati Podravinu od ostalih turističkih destinacija.

\section{Prijedlozi brendiranja Podravine}

Za brendiranje je potrebno utvrditi ključne atribute, a za destinaciju Podravina bili bi to ovi: kultura i tradicija, ruralni lifestyle, atrakcije i iskustva, te dostupnost. Podravina bi se njima turistički brendirala i pozicionirala kao atraktivna, jedinstvena i vjerodostojna destinacija. To konkretno znači da se u destinaciji razvija i da postoji turistički proizvod koji je iskoristio resursnu osnovu i turistički je predstavio na atraktivan način i radi kreiranja doživljaja i iskustava s izbalansiranim omjerom kvalitete i cijene. Jedinstvenost se ogleda

\footnotetext{
${ }^{19}$ Philip KOTLER, Upravljanje marketingom, Zagreb, Mate, 2008, 274.

${ }^{20}$ Berislav BOLFEK, Darija JAKIČIĆ, Biljana LONČARIĆ, Polazišta za brendiranje Slavonije kao turističke destinacije, Ekonomski vjesnik, 25 (2012) 2, 363-375.
} 
u korištenju atrakcijske osnove specifične za destinaciju Podravina na temelju koje se područje diferencira od konkurenata. Vjerodostojnost znači da se kod posjetitelja-turista stvara osjećaj vrijednosti turističkog proizvoda i usluga koje se mogu dobiti u realnom vremenu. Atraktivnost, jedinstvenost i vjerodostojnost - mogućnosti su destinacije Podravina za izgradnju i postizanje kompetitivne pozicije na tržištima.

\subsection{Definiranje PoPs (točke jednakosti) i PoDs (točke različitosti)}

Na globalnom turističkom tržištu postoji mnogo turističkih destinacija koje su izgradile svoj prepoznatljiv imidž i podižu svoju konkurentnost procesom brendiranja. Velik izbor prepoznatljivih destinacija znači da sve nove destinacije koje na turističkom tržištu žele izgraditi brend moraju pronaći način, odnosno one elemente koji bi destinaciju mogli izdvojiti od konkurencije. Pozicioniranje turističke destinacije ili način na koji potencijalni turisti percipiraju brend u konačnici je ono što će utjecati da odaberu baš tu destinaciju u odnosu na konkurentnu. U provođenju strategije brendiranja koriste se dvije metode kojima se definira pozicioniranje turističke destinacije, a to su Points of Parity (PoPs) - točke jednakosti i Points of Difference (PoDs) - točke različitosti. ${ }^{21}$

PoPs, Points of Parity, odnosno točke jednakosti, jesu resursi koji povećavaju konkurentnost područja. Imaju ih i ostale konkurentne destinacije i smatraju se atraktivnim faktorima koji potiču motivaciju. Ne moraju biti razlog da se odabere ta destinacija, ali ako ih nema to može biti snažan razlog da se destinacija ne odabere, odnosno da se smatra neatraktivnom. ${ }^{22}$ Točke jednakosti za destinaciju Podravina su:

a) kulturna etnološka baština: folklor (narodne nošnje, oživljena prezentacija nematerijalne kulturne baštine), narodno stvaralaštvo, tradicijsko graditeljstvo, povijesna mjesta (Križevci, Koprivnica, Đurđevac), kultiviran krajolik; b) ponuda tradicijskih specijaliteta podravske kuhinje i c) tipični proizvodi: vino, bučino ulje.

PoDs, Points of Difference, odnosno točke različitosti, su oni resursi koji postižu ekskluzivnost, ne mogu se naći kod drugih destinacija, specifični su i neponovljivi i na njima destinacija gradi ekskluzivnost i tržišnu prepoznatljivost. ${ }^{23}$ Za destinaciju Podravina točke različitosti su:

\footnotetext{
${ }^{21}$ Jo HYOK-GUN, A Harmony between Point of Parity and Point of Difference for the Improvement of Positioning, u: Computer Applications for Software Engineering, Disaster Recovery, and Business Continuity, International Conferences, ASEA and DRBC 2012, Held in Conjunction with GST 2012, Jeju Island, Korea, 28.11.-2.12.2012, Proceedings, Cham, Switzerland, Springer Nature Switzerland AG, 2012, 348-352.

${ }^{22}$ Isto, 348-350.

${ }^{23}$ Isto.
} 
a) Podravska naiva. Podrazumijeva likovno stvaralaštvo samoukih običnih ljudi iz naroda, a krasi je prepoznatljiv stil prepun »pomaka« u proporcijama i perspektivi koji se jedinstvenom tehnikom prenosi na staklo. Naivno slikarstvo Podravine koristi motive svakodnevnog seoskog života, smirenih krajolika, minulih vremena, slavljenja života, ali i tragičnih i socijalno nepovoljnih aspekata življenja. Naivna umjetnost kao oblik likovnog izraza u Hrvatskoj ima veliku tradiciju, posebno u Podravini iz koje je niz slikara neospornog ugleda i vrijednosti: Ivan Lacković Croata, Ivan Generalić, Mijo Kovačić, Ivan Večenaj i drugi. ${ }^{24} \mathrm{U}$ fokusu podravske naive kao specifični izričaj je podravsko selo i njegov svakodnevni život kroz sva godišnja doba i sve životne situacije. Podravska naiva prikazuje podravsko selo onako kako ga sami autori, kao ljudi iz Podravine i naroda, osjećaju i prenose na staklo posebnom tehnikom. Ona je najjača točka različitosti na kojoj destinacija Podravina može izgraditi svoju tržišnu prepoznatljivost i konkurentnost na globalnom turističkom tržištu putem atraktivnih turističkih proizvoda.

b) Televizijska serija »Gruntovčani« je točka različitosti kojom se može dodatno izgraditi konkurentnost i turistička prepoznatljivost na domaćem turističkom tržištu. Serija je snimana u podravskom selu Sigetec i težište priče je ruralna sredina i život u Podravini. Na osebujan i zanimljiv način serija utjelovljuje »duh mjesta« i svojevrstan podravski način života kroz deset jednosatnih epizoda. Seriju je proizvela RTV Zagreb, a emitirana je na malim ekranima 1975. godine postigavši ogromnu popularnost i gledanost i na taj način doprinijela je prepoznatljivosti Podravine kao regije. ${ }^{25}$

\section{c) Legenda o Picokima}

»Uz utvrdu Stari grad u Đurđevcu iz 14. stoljeća vezana je priča, legenda o Picokima, opstala usmenom narodnom predajom, temeljena na povijesnim događajima iz vremena osmanskih osvajanja polovicom 16. stoljeća kada je ista vojska nadirući s istoka željela osvojiti što veće područje, pa tako i važnu obrambenu, uporišnu točku - utvrdu Stari grad. Zahvaljujući lukavstvu jedne starice, na njen prijedlog kapetanu grada, branitelji su iz topa ispalili pjetlića picoka zbog čega su Osmanlije zaključili da u utvrdi ima hrane u izobilju. Bio

\footnotetext{
${ }^{24}$ Hrvatski muzej naivne umjetnosti, Zagreb, Art Studio Azinović, 2003; Vladimir CRNKOVIĆ, Studije i eseji, recenzije i zapisi, interpretacije: prilozi za teoriju i povijest naive i art-brutističkih tendencija, Zagreb, Hrvatski muzej naivne umjetnosti, Društvo povjesničara umjetnosti Hrvatske, Krapina, Kratis, 2002; Isti, Hrvatski muzej naivne umjetnosti, Zagreb, Hrvatski muzej naivne umjetnosti, 2000; Božica JELUŠIĆ, Znak na zemlji. Podravsko slikarstvo i kiparstvo, Koprivnica, Lora, 1996; Ratko VINCE, Čudo hrvatske naive, Zagreb, Amalteja, 1996; Marijan ŠPOLJAR, Podravska naiva. Vodič, Koprivnica, Markop, 1991; Krsto HEGEDUŠIĆ, Podravski motivi. 34 crteža (predg. Miroslav Krleža), Zagreb, Liber, 1971.

${ }^{25}$ Petar KRELJA, Golik, Zagreb, Hrvatski državni arhiv - Hrvatska kinoteka, 1997; HRT, Početna, Leksikon radija i televizije, G, Gruntovčani, https://obljetnica.hrt.hr/leksikon/g/gruntovcani/ (31.07.2020).
} 
je to razlog da prestanu opsadu i krenu dalje, nazvavši žitelje grada Picokima, imenom koje i danas Đurđevčani s ponosom nose. $\aleph^{26}$

Ova legenda je specifična s obzirom na to da nema podataka o tome da $\mathrm{u}$ svijetu postoji koja slična. Scensko oživljavanje »Legende o Picokima« jedinstvena je scenska priredba i osobit vizualno-zvučni doživljaj. Proglašena je nematerijalnim kulturnim dobrom Republike Hrvatske, te je u toj kategoriji 2008. godine postala nacionalni pobjednik i član Europske mreže turističkih destinacija izvrsnosti (European destination of exellence - EDEN). ${ }^{27}$

d) Vegeta je prehrambeni proizvod tvornice »Podravka« iz Koprivnice, začin, dodatak jelima, mješavina soli i sušenog povrća i začinskoga bilja. Vegetu je 1959. godine osmislila Zlata Bartl, koja je u to vrijeme bila voditeljica tima $\mathrm{u}$ istraživačkom laboratoriju Podravke. ${ }^{28}$ Dvije godine poslije proizvodnja se povećala na tada respektabilnih 16 tona. Dvanaest godina od izuma, Vegeta 1971. godine mijenja ime iz »Vegeta $40 \ll u$ $»$ Vegeta «, a postigla je međunarodnu prepoznatliivost kao industrijski proizvod. Danas se prodaje u više od 50 zemalja svijeta. Daljnjim razvojem proizvoda, 1974. godine, brand dobiva svoju kulinarsku emisiju »Male tajne velikih majstora kuhinje«, s poznatim dvojcem, voditeljem Oliverom Mlakarom i kuharom Stevom Karapandžom. Od 1989. godine Vegeta se izvozi na tri kontinenta: Europu, Ameriku i Australiju. Tijekom godina postojanja, daljnjim rastom potreba, uvedene su i dodatne linije proizvoda Vegeta s različitim namjenama (Mediteran, Classic, Natur, Grill i Twist). U više od 50 godina na tržištu, Vegeta je osvojila brojne nagrade i priznanja za kvalitetu. ${ }^{29}$ Zbog svoje prepoznatljivosti na međunarodnim tržištima, Vegeta kao proizvod ima mogućnost sudjelovati u razvoju turističkog brenda destinacije Podravina kroz ponudu industrijskog turizma. Industrijski turizam je turizam specijalnih interesa koji se organizira u postojećim industrijskim postrojenjima s aktivnom proizvodnjom, kao i u objektima koji su proglašeni kao industrijsko kulturno dobro, $\mathrm{u}$ kojima nema aktivne industrijske proizvodnje. ${ }^{30} \mathrm{U}$ tom smislu koprivnička tvornica »Podravka« ima mogućnost doprinijeti brendiranju regije Podravina organizacijom turističke ponude (turističkih tura) za potencijalne turiste koji bi bili zainteresirani za neposrednu

\footnotetext{
${ }^{26}$ Muzej grada Đurđevca, Legenda o Picokima, https://muzej-djurdjevac.hr/utvrda-stari-grad/ legenda-o-picokima/ (31.07.2020).

${ }^{27}$ Grad Đurđevac, Kultura i sport. Legenda o Picokima, https://djurdjevac.hr/kultura-i-sport/ legenda-o-picokima/ (31.07.2020); Turistička zajednica Koprivničko-križevačke županije, Podravina i Prigorje, Manifestacije-događanja, Picokijada, https://tz-koprivnicko-krizevacka.hr/ manifestacije-dogadanja/picokijada/ (31.07.2020).

${ }^{28}$ PODRAVKA, Kako je nastala Vegeta?, https://www.podravka.hr/clanak/2001664/kako-je-nastala-vegeta/ (31.07.2020).

${ }^{29}$ HRVATSKA GOSPODARSKA KOMORA, Znakovi hrvatske kvalitete, Proizvod, Vegeta, https://znakovi.hgk.hr/proizvod/vegeta/ (31.07.2020).

${ }^{30}$ Jasmina GRŽINIC, Patricia ZANKETIĆ, Robert BAĆAC, Industrijski turizam u Istri, Ekonomska misao i praksa, 18 (2009) 2, 211-232.
} 
prezentaciju proizvodnje Vegete, kao međunarodno prepoznatljivog proizvoda, na mjestu njegova nastanka.

Za izgradnju brenda destinacije Podravina, prema definiranim točkama različitosti radi postizanja vidljivosti na tržištu i izgradnje identiteta, bit će potrebno dati pozornost sljedećem:

a) Za razliku od brenda komercijalnih proizvoda, koji bi mogli biti zloupotrijebljeni ako ih koriste drugi, destinacijski brend povećava vrijednost što se više upotrebljava od strane drugih partnerskih organizacija. Što ga više koriste različiti dionici, destinacijski brend će biti vidljiviji, imat će veću tržišnu prodornost i bit će primjetljiviji.

b) Najmoćniji način širenja destinacijskog brenda jest uvjeriti odgovarajuće partnere i/ili dionike da prenesu vrijednosti brenda u vlastitim marketinškim komunikacijama.

c) Treba definirati i utvrditi ključne dionike koji bi bili prikladni i spremni za uključivanje brenda destinacije u svoje marketinške komunikacije.

d) Uključiti i neturističke dionike (npr. zrakoplovne kompanije, filmsku industriju itd.) koji imaju utjecaja na tržište, putem kojih bi brend komunicirao s tržištem na podjednak način kao i kroz turističke dionike.

e) Pažljivo kontrolirati korištenje logotipa destinacije putem licenciranja samo za ovlaštene korisnike ne bi nastala šteta ako brend koristi dionik koji ima lošu reputaciju na tržištu ili je nepouzdan.

\section{Zaključak}

U proces izgradnje turističkog brenda destinacije Podravina i kasnijeg uspješnog implementiranja bit će potrebno: a) povećati vidljivosti destinacije Podravina putem iskustvenih turističkih proizvoda, što uključuje kulturu i baštinu, povijest, ljude, prirodu, davanje turistima bogatijeg i višedimenzionalnijeg iskustva; b) kreirati prepoznatljiv profil destinacije Podravina, pri čemu je prioritet kulturna revalorizacija Podravine kreiranjem iskustava i doživljaja kao okosnice turističkog brendiranja. Ispunjenje ovog cilja mora dati odgovor na pitanje zbog čega bi turisti za svoju destinaciju odabrali Podravinu; c) dokazati dostupnost destinacije Podravina komunicirajući postojanje turističke infrastrukture, proizvoda i usluga potrebnih turistima. Dokazati da Podravina nije daleko, da u nju nije komplicirano doći, da je lako moguće rezervirati usluge, kombinirati različite sadržaje, aktivno istraživati područje i biti u interakciji s lokalnim stanovništvom; d) promovirati aktivne interakcije ponudom iskustvenih doživljaja kreiranih za turiste u kojima oni aktivno sudjeluju; e) održavati brend, što znači aktivno uključivati posjetitelje-turiste u vrijednosti destinacije 
Podravina, te na temelju njihovih povratnih informacija brend neprestano nadograđivati i širiti.

Također, u procesu implementacije brendiranja morat će biti obuhvaćene sve potrebne ključne točke za stvaranje prepoznatliive tržišne robne marke destinacije Podravina, a to su: a) razlikovanje destinacije Podravina od njezinih konkurenata; b) povećanje svijesti o Podravini i prepoznavanje Podravine od strane potencijalnih posjetitelja-turista (Aha efekt); c) stvaranje pozitivne slike o Podravini kao destinaciji, koristeći pomno osmišljene marketinške poruke radi usmjeravanja fokusa potencijalnih posjetitelja-turista i d) davanje destinaciji Podravina snažan identitet kreiranjem brenda.

Prilikom istraživanja za potrebe ovoga rada postojala su objektivna ograničenja, a najvažnija su: nepostojanje istraživanja, znanstvenih i stručnih radova, studija, strategija, razvojnih planova i ostalih dokumenata o brendiranju Podravine kao turističke destinacije kao i nepostojanje istraživanja preferencija i stavova turista/posjetitelja destinacije Podravine, prije svega Koprivničko-križevačke županije, o motivima dolazaka u destinaciju te stavovima i mjerenju zadovoljstva postojećim turističkim proizvodima, što onemogućuje definiranje stupnja prepoznatljivosti Podravine na domaćem i međunarodnom turističkom tržištu.

U tom smislu ovaj je rad vrijedan i rijedak znanstveni prilog istraživanja brendiranja turističkih destinacija općenito, u kojem su predstavljeni i protumačeni prijedlozi za brendiranje Podravine prema rezultatima istraživanja točki jednakosti i točki različitosti. Također, može biti poticaj za daljnja znanstvena i stručna istraživanja teme brendiranja i razrađivanja mogućih turističkih procesa u razvoju turizma destinacije. Ovaj rad ima i praktičan doprinos budući da predlaže kreiranje konkretnih i konkurentnih turističkih proizvoda koji imaju za cilj ponuditi gostu/posjetitelju dodanu vrijednost kroz doživljaj i iskustvo, na temelju kojih je moguće pokrenuti proces brendiranja destinacije Podravina. Naposljetku, važan praktičan doprinos ovoga rada je i u tome što ga se može smatrati svojevrsnim modelom, odnosno predloškom da stručna, zainteresirana javnost može sagledati mogućnosti brendiranja i neke druge kontinentalne destinacije koja još nije započela proces brendiranja da bi poboljšala izgradnju konkurentnosti i tržišnu prednost naspram jadranskih destinacija koje su brendiranje već provele. 


\section{Robert Baćac* - Damir Demonja*** \\ Tourist Destination Branding: The Example of Podravina}

Summary

Podravina as a cultural-historical term is a recognizable geographical area in the Republic of Croatia that includes the territory between the Drava river, the mountains of Bilogora and Kalnik hills. Today, this area is part of a unique administrative and political entity of Koprivnica-Križevci County. In terms of tourism, Podravina is a separate entity, in particular historical, cultural, natural and social destination with its own specifics and resources. Podravina has an adequate number of unique and valuable tourist attractions that have the potential to attract tourists. However, in the example of Podravina, these attractions are not articulated in such a way as to differentiate Podravina more strongly, more clearly against the competition, and tourists should be offered a unique experience based on the synergy of existing facilities at the disposal of Podravina. This will be possible by starting the process of building the tourist brand of Podravina. Podravina branding is the creation of a competitive identity that will differentiate this destination from all others. The brand itself is determined by the basic characteristics of the destination, its advantages arising from the resource base, which is its personality, and make it recognizable and different from competitors. This scientific paper presents and explains the reasons and needs, i. e. the necessity of branding a destination with reference to the global context and competitive environment, explains the types of branding, and for the first time for Podravina defines PoPs, Points of Parity, and PoDs, Points of Difference, on the basis of which the destination Podravina would build its values and recognizability in terms of tourism. Following them, branding factors that are crucial for brand building are proposed and explained, concluding with the steps of the Podravina tourist brand building process and successful implementation of all factors of creating a recognizable market brand of Podravina. Considering that a review of recent scientific and professional literature shows that the tourist branding of Podravina has not been discussed in the Croatian academic public, this scientific paper is one of the first to address this important topic.

Key words: branding, destination recognition, Podravina, tourism, tourist positioning.

(na engl. prev. Damir Demonja)

\footnotetext{
* Robert Baćac, BEc, Independent consultant; Address: Giardini 2, HR-52100 Pula, Croatia; Email: robert.bacac@pu.t-com.hr.

*Damir Demonja, PhD, Research Adviser in permanent position, Institute for Development and International Relations, IRMO, Department for International Economic and Political Relations; Address: Ljudevita F. Vukotinovića 2, HR-10000 Zagreb, Croatia; E-mail: ddemonja@ irmo.hr.
} 